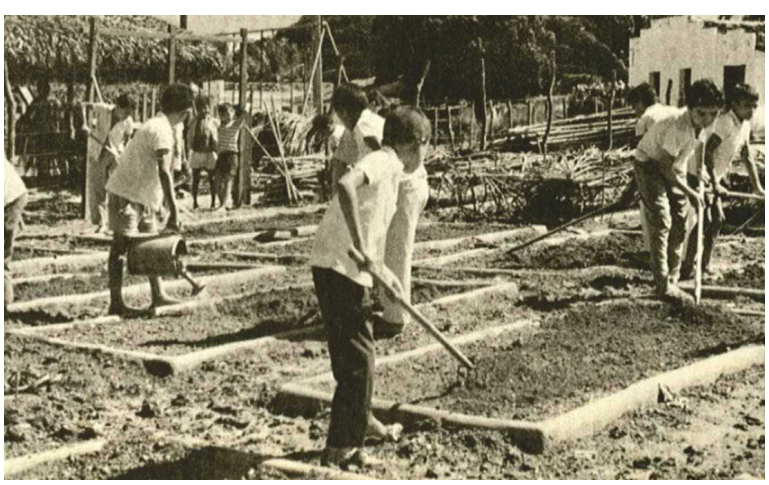

*Licenciada em Geografia (Universidade Federal do Rio Grande do Norte, 2010), formada em Arquitetura e Urbanismo (Universidade Potiguar, 2016). Atualmente é mestranda da Pós-graduação em Arquitetura e Urbanismo da Universidade São Judas Tadeu (São Paulo/SP) na linha de pesquisa em Gestão do espaço Urbano, onde tem estudado os desdobramentos de uma campanha educacional em Natal para políticas de gestão urbana.
**Professora do Programa de Pós Gradação em Arquitetura e Urbanismo (2008), Mestrado Profissional em Engenharia Civil e do Curso de Graduação (2003) da Universidade São Judas. Pós doutora pelo Instituto de Estudos Brasileiros da Universidade de São Paulo (2018). Arquiteta e Urbanista pela Escola de Engenharia de São Carlos- USP (1991), mestre pela mesma instituição (1999) e doutora pela FAUUSP (2005).

\title{
A utopia popular materializada nos Acampamentos Escolares da Campanha De Pé no Chão Também se Aprende a Ler (Djalma Maranhão, Natal-RN, 1961)
}

The popular utopia materialized in the School Camps of the campaign Standing on the ground also learns to read (Djallma Maranhão, Natal-RN, 1961)

Maria Helena Paiva da Costa* e Ana Paula Koury ${ }^{\star *}$

\section{Resumo}

No início da década de 1960 o Brasil vê o surgimento de inúmeras experiências educacionais no combate ao analfabetismo. Nesse contexto surge em 1961, na cidade de Natal/RN a campanha De Pé no Chão Também se Aprende a Ler, que entendemos ter sido possível devido à forte atuação popular e atitude política comprometida com os anseios da população pelo acesso à educação. Buscamos contextualizar a arquitetura utilizada no espaço escolar, que ficou conhecido como Acampamentos Escolares, enfatizando o conhecimento vernacular presente na construção dos acampamentos, relacionando-os à tipologia dos mocambos estudada, na década de 1930, pelo sociólogo pernambucano Gilberto Freyre.

Palavras-chave: Arquitetura popular. Conhecimento vernacular. Participação popular.
Abstract

In the early 1960s Brazil saw the emergence of countless educational experiences in combating illiteracy. In this context, in 1961, in the city of Natal / RN, the campaign De Pé no Chão Também se Aprende a Ler (Standing on the ground also learns to read), which we believe to have been possible due to the strong popular performance and political attitude committed to the population's desire for access to education. We sought to contextualize the architecture used in the school space, which became known in the construction of the School Camps, emphasizing the vernacular knowledge present in the camps, relating them to the typology of the mocambos studied in the 1930s by the sociologist from Pernambuco Gilberto Freyre.

Keywords: Popular architecture. Vernacular knowledge. Popular participation. 


\section{Apresentação}

Este trabalho analisa a campanha de Dé Pé no Chão Também se Aprende a Ler, que ocorreu em Natal/ RN entre os anos de 1961 a 1964, durante a segunda gestão municipal do prefeito Djalma Maranhão. A campanha foi uma política pública para a área de educação e é um exemplo de participação ativa da população na produção do espaço e na gestão dos serviços públicos.

O interesse pela Campanha reside nas especificidades, sobretudo em seu pioneirismo em adotar na arquitetura da rede escolar um sistema construtivo baseado em técnicas populares do Nordeste como a estrutura em troncos roliços e a cobertura em palha trançada. A proposta foge aos padrões convencionais do que se entende como arquitetura escolar, que resultou nos chamados: Acampamentos Escolares.

Assim, com este artigo pretendemos documentar e estabelecer significado para a história da arquitetura popular brasileira de um programa escolar desconhecido pela área de Arquitetura e Urbanismo e que produziu um sistema espacial de grande potencial simbólico para a cidade de Natal.

Metodologicamente, trabalhamos com a pesquisa histórico-comparativa, onde nos baseamos em fontes primárias e entrevistas. Fizemos revisão bibliográfica da pouca literatura específica sobre a campanha, lidando principalmente com a produção de Moacyr de Góes (1930-2009), que era o Secretário de Educação em 1961, e do professor José Willington Germano, pesquisador da campanha. Também pesquisamos o acervo do Arquivo Público Estadual e o acervo audiovisual da central de documentação do site <dhnet.org. br>, ambos localizados em Natal/ RN. Realizamos duas entrevistas com personagens fundamentais para a campanha, Sr. Ribamar, mestre-de-obras da prefeitura na época e a Dona Nair, professora 
1. O livro intitulado "De Pé no Chão Também se Aprende a Ler (A Escola Brasileira com dinheiro brasileiro, uma experiência válida para o mundo subdesenvolvido)" não chegou a ser finalizado. A editora que o publicaria seria a Civilização Brasileira S.A. de uma das escolas. Outra importante contribuição para esta pesquisa foi o encontro com Gabriel Monte, arquiteto e urbanista, em Natal /RN. Neste artigo há o empenho em relacionar as discussões do campo da Arquitetura e Urbanismo sem perder de vista aspectos da Pedagogia, História, Política, Sociologia, Antropologia e demais áreas do conhecimento que contribuem para a compreensão do processo participativo na implementação da campanha De Pé no Chão e da sua arquitetura.

Apresentamos a campanha De Pé no Chão com suas particularidades construtivas e funcionais, apontando o caráter singular da arquitetura empregada em De Pé no Chão que se utiliza de métodos construtivos pautados no conhecimento vernacular e, a partir desta característica, apontamos as semelhanças com as construções dos mocambos estudados pelo sociólogo Gilberto Freyre na década de 1930.

\section{Djalma Maranhão e seu crime: a educação po- pular}

No final da década de 1950 a população de Natal escolhia, pela primeira vez, o seu representante municipal, Djalma Maranhão. Mas esta não seria a primeira vez que Djalma Maranhão governaria Natal. Ele havia sido indicado para a função pelo governador do Estado Dinarte Mariz (UDN) para exercer o cargo entre 1956-1959 e voltaria ree- leito em 1960, empreendendo uma gestão fortemente marcada pelo apoio e mobilização popular. Mas esta seria a última eleição direta da capita do Rio Grande do Norte até a redemocratização do país quando ocorreram as novas eleições municipais por voto direto em 1989. O golpe empresarial - militar que depôs o presidente João Goulart em 01 de abril de 1964 encerrou a breve e profícua experiência democrática de base popular em Natal conduzida por Djalma Maranhão. (GÓES, 1997).

O prefeito exerceu o seu cargo até 02 de abril de 1964, quando foi afastado pelo novo regime. Foi preso em Natal, depois levado para Fernando de Noronha e Recife, e após estas prisões ficou exilado em Montevidéu, no Uruguai, aonde faleceu em 1971.

Djalma Maranhão relata, em seu livro' ${ }^{1}$ escrito no exílio, que quando foi levado da prisão para ser identificado na Secretaria de Segurança, ao passar por um das edificações da campanha De Pé no chão Também se Aprende a Ler, falou ao militar que o conduzia: "Está aí a prova material do nosso crime". (MARANHÃO [?], p. 134). Mais a frente, MARANHÃO cita que: "A experiência de educação de massas, estava se transformando em realidade, até que o golpe militar a considerou subversiva. Estranha subversão que arrancava dos olhos do povo a mancha negra do analfabetismo". (MARANHÃO, [?], p 135). 
Djalma Maranhão havia militado no partido comunista na década de 1940, e na década de 1950 estava ligado à base de apoio político de Café Filho no Rio Grande do Norte. Na composição política da sucessão presidencial de 1950 da qual Getúlio Vargas saiu vencedor por voto direto, Café Filho foi uma peça fundamental. Indicado para o cargo de vice-presidente pelo PSP (Partido Social Progressista) fundado por Ademar de Barros para integrar a chapa do PTB que lançou a candidatura de Vargas. A coligação foi denominada de "aliança populista" devido à forma demagógica dos discursos e prática política de Ademar de Barros em São Paulo. (D'ARAÚJO, 1986 e GÓES, 1997).

Em seu primeiro mandato, o prefeito Djalma Maranhão (1956 - 1959) criou um programa educacional chamado de Escolinhas, que consistia em uma iniciativa da gestão municipal para que a educação popular atingisse diversos bairros da cidade.

[...] onde fosse cedida, gratuitamente, sem cobrança de aluguel, uma sala, aí seria instalada uma "escolinha". Sindicatos, sociedades beneficentes, sedes de clubes de futebol, igrejas de todos os credos, residências particulares, abriram as suas portas. Nestes lugares, passaram a funcionar escolas [...] (I Encontro Nacional de Alfabetização e Cultura Popular NATAL, 1963, p. 06).

Góes (2010) afirma que Djalma Maranhão era um prefeito das massas e procurava atender as rein- vindicações da população. Fazia reuniões com os populares nos bairros da cidade ainda durante a sua campanha eleitoral, para descobrir as principais necessidades da população. Ao final da sua campanha eleitoral encontrou uma reinvindicação unânime, a população queria ter acesso à educação, queria seus filhos matriculados em escolas públicas sem restrição de acesso.

No cargo de prefeito de Natal Djalma Maranhão, juntamente com Moacyr de Góes, então secretário de educação municipal, lançaram a campanha de erradicação do analfabetismo em Natal, pouco tempo depois intitulada de "De Pé no Chão Também se Aprende a Ler".

\section{De Pé no Chão Também se Aprende a Ler: re- latos de uma campanha popular}

Ainda durante a campanha eleitoral ao cargo de prefeito, de janeiro a outubro de 1960, Djalma Maranhão buscou o apoio das camadas populares através da criação de Comitês Nacionalistas que se espalhavam pelos bairros periféricos da cidade. Ao descrever como funcionava a atuação dos comitês em uma entrevista, Góes (2004) afirma que:

É um agrupamento de homens e mulheres, em número variável, desburocratizado, que recebe em uma casa comum de qualquer rua, Djalma Maranhão e colaboradores, com eles discutem os problemas dos bairros e da cidade. Essas discussões levam à necessidade de organização 
de núcleos dispostos a reivindicar, trabalhar e ganhar as eleições em 3 de outubro de 1960. (GÓES, 2004, p. 219).

Os comitês tiveram um papel importante na conscientização política da população "ouviam e discutiam" com os cidadãos, e por isso "foi possível à população propor e organizar um programa de governo para o município" como descreve Góes, (2010, p. 42). Foi durante as discussões no bairro das Rocas que se levantou a principal reivindicação da população, o acesso irrestrito da população à educação pública. As condições de ingresso e permanência nas escolas públicas existentes afastavam as populações pobres que não tinham condições de se adequar ao fardamento e ao desempenho imposto por um sistema de educação pública de qualidade, mas também seletivo e elitizado. Juntos, o governo municipal e a população do bairro, organizada na forma do Comitê Nacionalista das Rocas, discutiam os meios de como fazer o programa de erradicação do analfabetismo vingar.

Góes (2010, p. 45) relata que em uma reunião da qual participaram uns "40 e 50 homens e mulheres" sugeriu que se não havia recursos para a construção dos edifícios, que se fizessem escolas com tetos de palha, que não precisava ter paredes, inclusive o chão podia ser de terra batida. Para a população o que importava era a prática educacional, e não a formalidade das construções estabelecidas no modelo da escola tradicional.
Estava então lançado o desafio de extinguir a cidade de Natal do mapa do analfabetismo da Nação. Era uma proposta ambiciosa, mas que tinha como maior motivação o apoio da população de Natal. A tática política do candidato funcionou e Djalma Maranhão foi eleito prefeito de Natal com o compromisso de realizar o programa de educação formulado através das consultas populares. Foi assim que a erradicação do analfabetismo através da implantação de uma rede de ensino municipal alternativa e popular tornou-se prioridade no segundo mandato de Djalma Maranhão como prefeito de Natal.

Para isso a secretaria de Educação, Cultura e Saúde foi criada e Moacyr de Góes foi o seu primeiro titular. A criação da Secretaria de Educação foi um importante passo para a implementação da campanha. De acordo com Germano (2010, p. 114) um dos grandes estudiosos da campanha, a primeira ação da secretaria foi criar o Grupo de Trabalho da Educação Popular que ficou "responsável pela sistematização inicial, que escolheu o bairro das Rocas como área-piloto da experiência".

O nome da campanha surgiu depois em uma reportagem realizada pelo jornalista Expedito Silva que afirmava "que até de pé no chão se aprende a ler" (I Encontro Nacional de Alfabetização e Cultura Popular, 1963, p. 05), fazendo referência à ideia de que o acesso à educação passaria a ser para todos, não mais um 


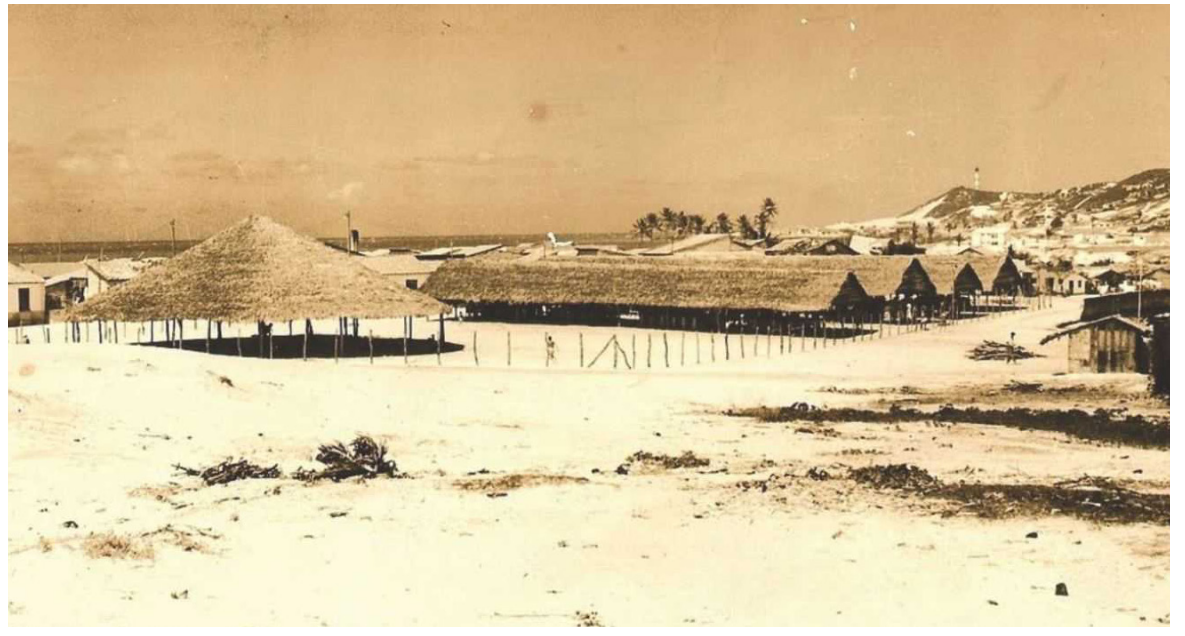

Figura 01. Acampamento Escolar das Rocas - Natal/RN, 1961. Fonte: DHNET, 1995.

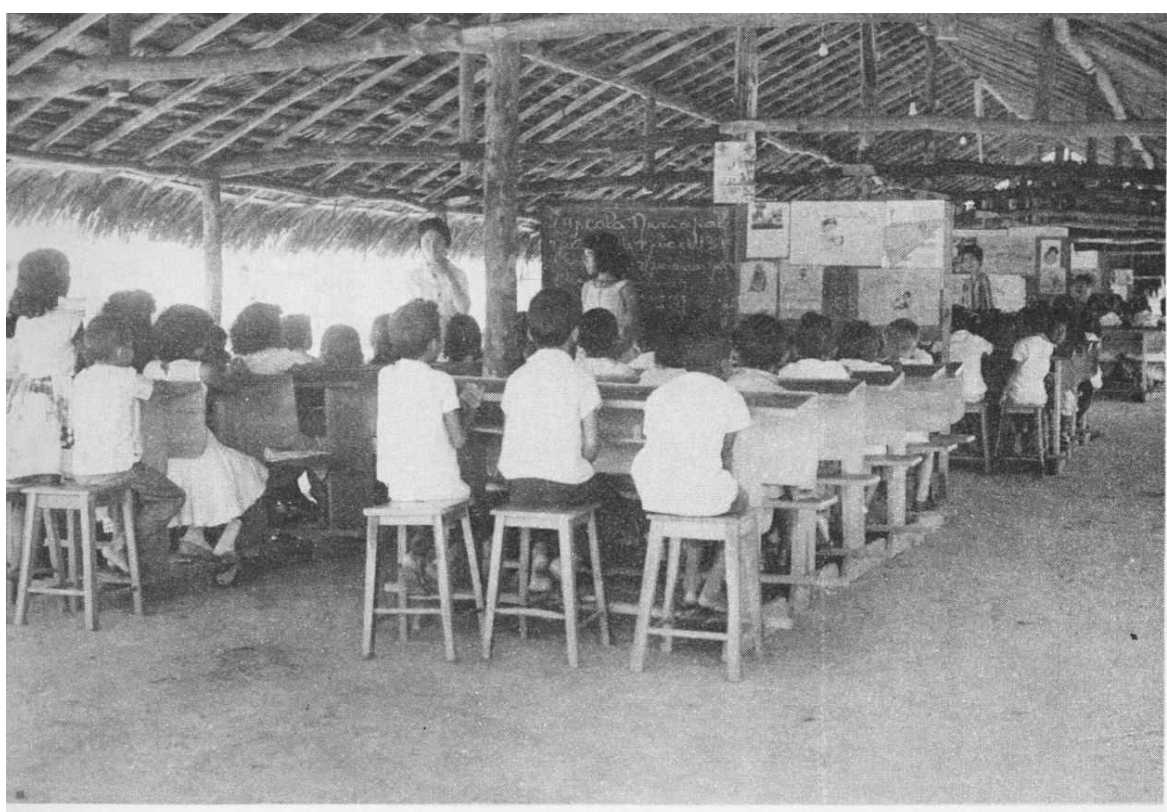

Cada galpão se divide em 4 salas de aula. Nos turnos da manhã e da tarde estudam adolescentes e crianças. À noite a freqüência é de adultos.

Figura 02. Galpão com salas de aula em um acampamento. . Fonte: DHNET, 1995. privilégio de poucos. O título torna-se ainda mais sugestivo se lembrarmos de que simbolicamente os sapatos eram os indicadores de ascensão social, portanto a campanha também operava com os elementos simbólicos da desigualdade social.

Como prometido para a população, o programa implantado pela secretaria de Educação e Saúde não fazia distinção entre os alunos, não havia restrições para as matrículas, não havia seleção de alunos e não havia fardamento escolar, elementos que restringiam o acesso da população mais pobre à rede pública existente.

\section{Os Acampamentos Escolares da utopia popu- lar materializada}

O projeto-piloto foi implantado no bairro das Rocas, situado na Zona Leste da capital e habitado por população de baixa renda. De fato, construiu-se a escola com estrutura de troncos sem apara, cobertura em de palha trançada, o piso em terra batida e sem paredes. Eram os "Acampamentos Escolares" (Figura 01).

O Acampamento Escolar do bairro das Rocas era constituído por quatro galpões que mediam $30 \mathrm{~m}$ $x 8 \mathrm{~m}$. Na imagem a seguir, a Figura 02 , vemos 0 interior de um galpão, que revela a simplicidade da construção, onde a divisão das salas era feita através quadros negros ou de quadros de avisos que não chegavam até o chão ou até o teto, assim como a ausência de paredes laterais. 


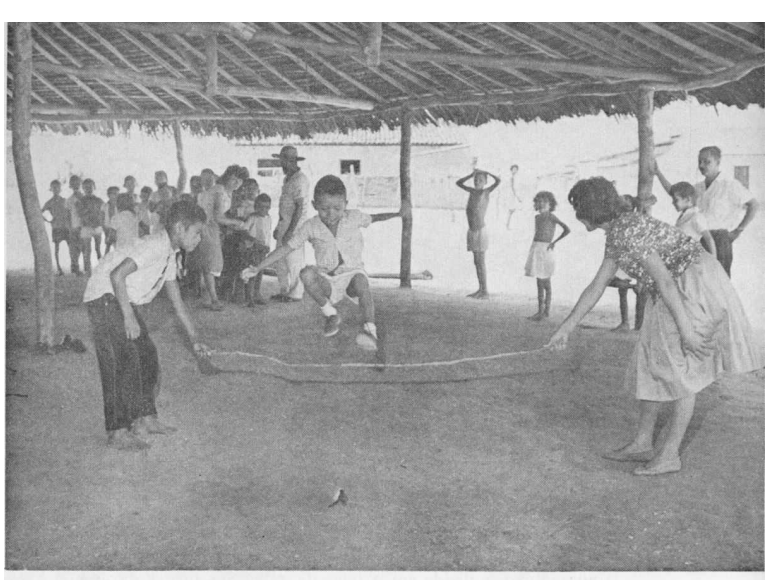

Uma escola alegre, sem repressão, e a merenda escolar: dois fatores de
combate à evasăo.

Figura 03. Espaço de convivência - palhoça circular. Fonte: DHNET, 1995.

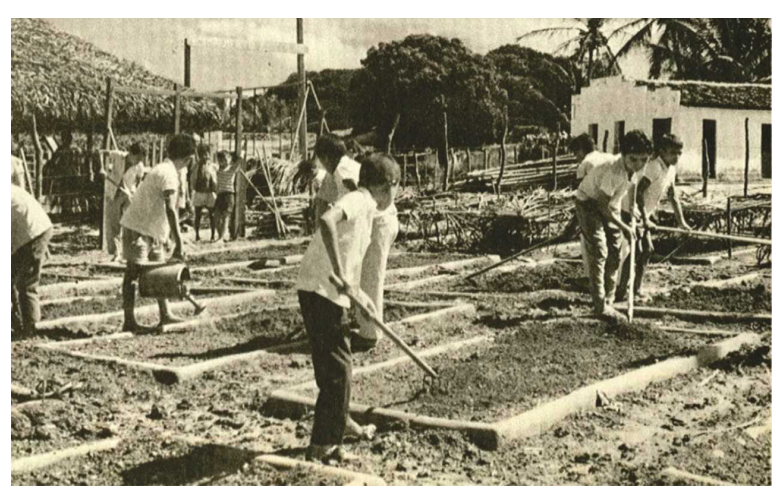

Figura 04. Alunos cuidando da horta para sustento da merenda escolar. Fonte: DHNET, 1995.

2. Gabriel Monte é arquiteto e urbanista em Natal e realizou um trabalho minucioso para a elaboração da maquete eletrônica do acampamento, através de referências biblio-

gráficas e depoimentos de pessoas que participaram da Campanha. Os relatos aconteceram na ocasião de uma conversa, em sua casa, no mês de setembro de 2017 .

usjt • arq.urb • número 25 | maio - agosto de 2019
Não havia isolamento de nenhum tipo, nem acústico, nem térmico e nem espacial. Isto é a paisagem estava dentro da sala de aula conforme descreve Góes (2010):

Os galpões destinados às salas de aula, em forma retangular, eram divididos internamente em quatro partes, através de pranchas, utilizadas como quadro-de-giz e quadro mural. Essas pranchas não atingem o teto nem o solo, nem fecham lateralmente a classe. Não existindo paredes externas, [...] e a visão espacial do recinto escolar/meio ambiente do Acampamento era total. (GÓES, 2010, p. 89).

Os galpões abrigavam as salas de aula e os serviços administrativos e havia, além deles, um espaço destinado às atividades sociais do bairro, como festas, reuniões de pais e professores e recreação. Era uma palhoça circular, com mesmo sistema construtivo dos galpões e não possuíam vedação alguma (Figura 03). Havia também um espaço externo destinado para o recreio dos jovens e crianças, era equipado com alguns brinquedos improvisados feitos de sucata.

Em anexo havia uma cozinha, o aviário, a horta, os banheiros e a cisterna. A cozinha era feita com lâminas de madeira e coberta com telhas de fibrocimento, ficava próxima ao aviário e a horta. O aviário fornecia a carne das aves e a horta abastecia de vegetais e leguminosas a merenda escolar. A horta e o aviário tinham um sentido pedagógico, uma vez que eram os alunos que cultivavam os alimentos (Figura 04) e cuidavam dos animais.
A produção deles é consumida pelos alunos na merenda diária - o que é um estímulo para o cuidado maior com as hortaliças e as aves. A campanha desperta o educando para a produtividade, demonstrando que as comunidades precisam se organizar na luta contra o pauperismo e a alienação da realidade. A educação simplesmente livresca já tem o seu atestado de óbito passado. (I Encontro Nacional de Alfabetização e Cultura Popular, 1963, p. 14).

Djalma Maranhão menciona o cultivo das hortaliças (Figura 04) e o cuidado com os animais para o autossustento da merenda nos Acampamentos Escolares em seu livro escrito durante o exílio no Uruguai:

As crianças plantavam hortaliças e algumas espécies de fruteiras, iniciando-se, assim, nos rudimentares princípios de agricultura. Tomate, pimentão, alface, mamão, etc., produzidos serviam para melhorar a merenda escolar. Tinha, também, outra finalidade, combater os tabus alimentares. Exemplo: tomar leite e comer determinadas frutas. (MARANHÃO, [?], p. 49)

Os Acampamentos Escolares não seguiam um projeto arquitetônico inicial, e o programa era adaptado de acordo com a necessidade da escola. A Figura 05 abaixo trata de ser um esquema de implantação do Acampamento Escolar do bairro das Rocas, com a localização espacial dos galpões e anexos no terreno. Foi traçado com a colaboração do arquiteto com Gabriel Monte², assim como através da observação de imagens e vídeos sobre a campanha. 


\section{delimitação do terreno}

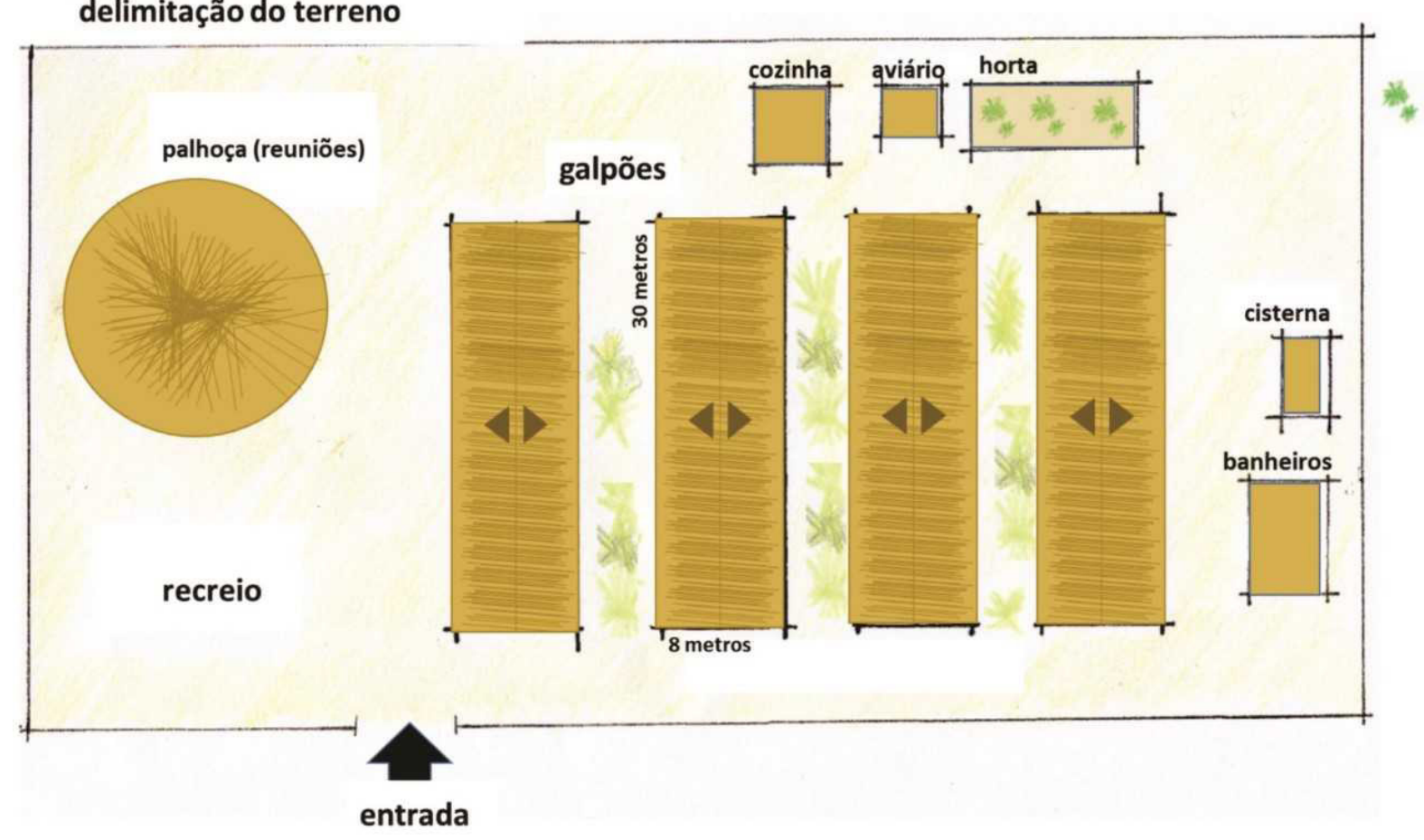

Figura 05. Croqui da implantação do acampamento das Rocas. Fonte: Acervo da autora.

Gabriel Monte relata que o piso de terra batida no interior dos galpões, era aterrado, ficando um pouco acima do nível do terreno arenoso em que foram implantados. A estrutura dos galpões era muito simples, em sistema de pilares e tesouras com cobertura de palha. As instalações elétricas também seguiam o mesmo princípio de simplicidade da estrutura, e eram compostas por lâmpadas penduradas pela fiação e presas a um bocal, distribuídas ao longo da estrutura central no sentido longitudinal do galpão.
O sistema construtivo era baseado na vegetação local, sendo o coqueiro a matéria prima que fornecia os materiais de construção para os Acampamentos Escolares. De seu tronco sairiam os pilares e de suas folhas trançadas sairia a cobertura em duas águas. Nas tesouras também era usada madeira de espécies locais. A inexistência de vedações permitia a ampla integração do edifício escolar com o ambiente, que fornecia a iluminação, a circulação do ar e a visual. Nas técnicas adotadas para a construção 
3. José Ribamar de Oliveira era funcionário da prefeitura, "braço-direito" do prefeito $e$ mestre de obras dos Acampamentos. O relato partiu de uma entrevista para a autora, em setembro de 2017, na residência dele, em Natal/RN.

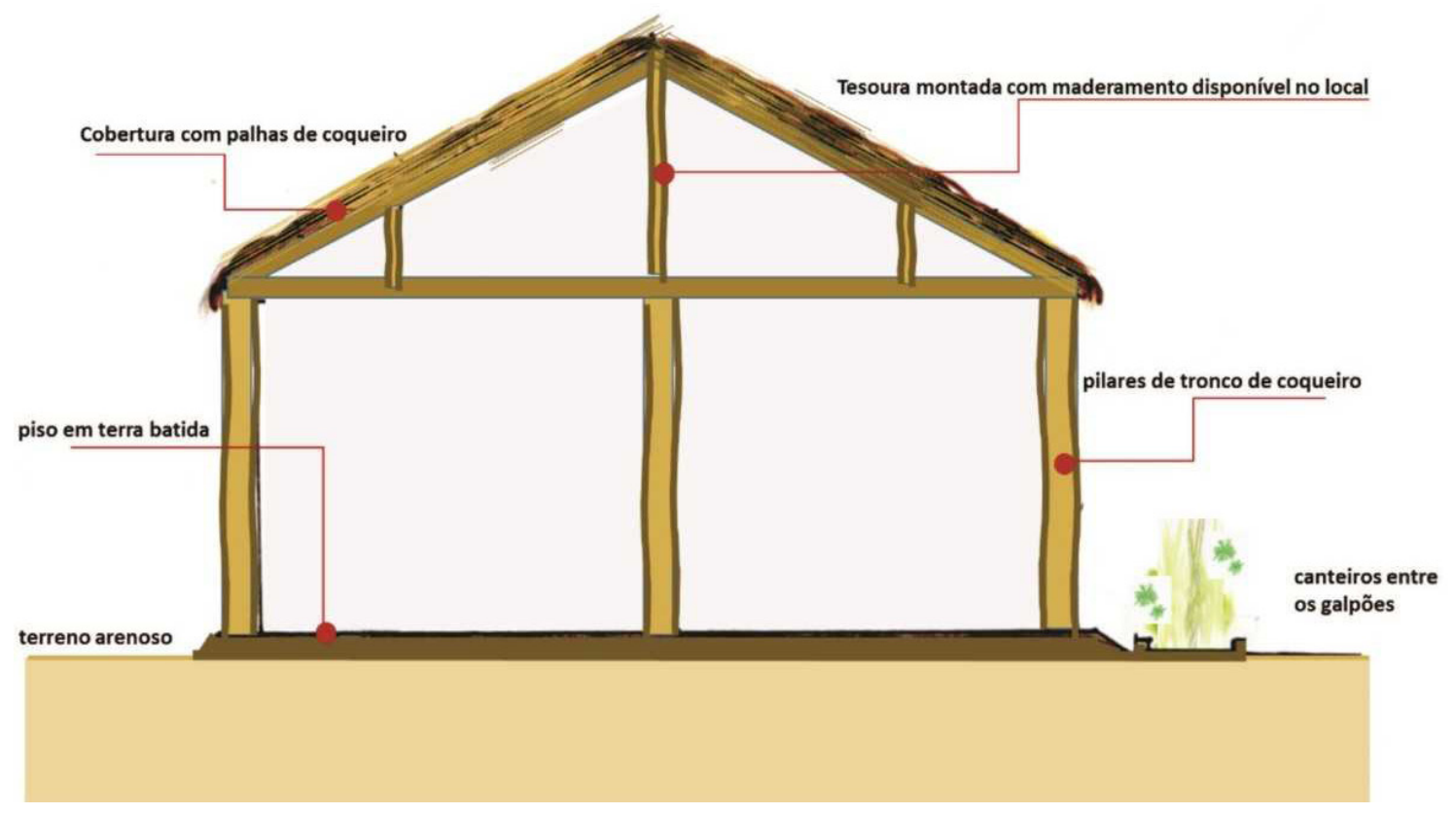

Figura 06. Croqui de corte esquemático de um galpão. Fonte: Acervo da autora.

dos acampamentos e nas suas características espaciais está materializada a cultura vernacular da região do litoral do Rio Grande do Norte.

Góes (2010, p. 135) relembra que os operários da prefeitura, já estavam adaptados às práticas urbanas da construção e que não sabiam como fazer a vira da palha para produzir a cobertura. Foi necessário trazer os pescadores do Canto do Mangue região da orla marítima, afastada do centro caracterizada pela economia da pesca artesanal. Lá os pescadores ainda cobriam as suas casas com a palha trançada dos coqueiros do litoral potiguar.
Além de Gabriel Monte, arquiteto e urbanista que estudou minuciosamente os Acampamentos Escolares, outra fonte importante de informações é o Sr. Ribamar ${ }^{3}$, funcionário da prefeitura naqueles anos e mestre de obras que trabalhou na construção dos galpões. O Sr. Ribamar explica que se a vira da palha não fosse feita corretamente a água da chuva não escoaria, infiltrando nos ambientes. Havia um modo de realizar o trançado que não era qualquer um que sabia fazer. Divergindo do relato de Góes, o Sr. Ribamar relata que foi levado por Djalma Maranhão para aprender a técnica da vira da palha com os pescadores do Canto do Mangue e teria sido ele quem teria pas- 
Os pescadores da região ensinaram aos operários da Prefeitura a virada da palha, para construir o teto do Acampamento Escolar. Essa técnica tinha sido esquecida pela mão-de-obra qualificada e urbana.

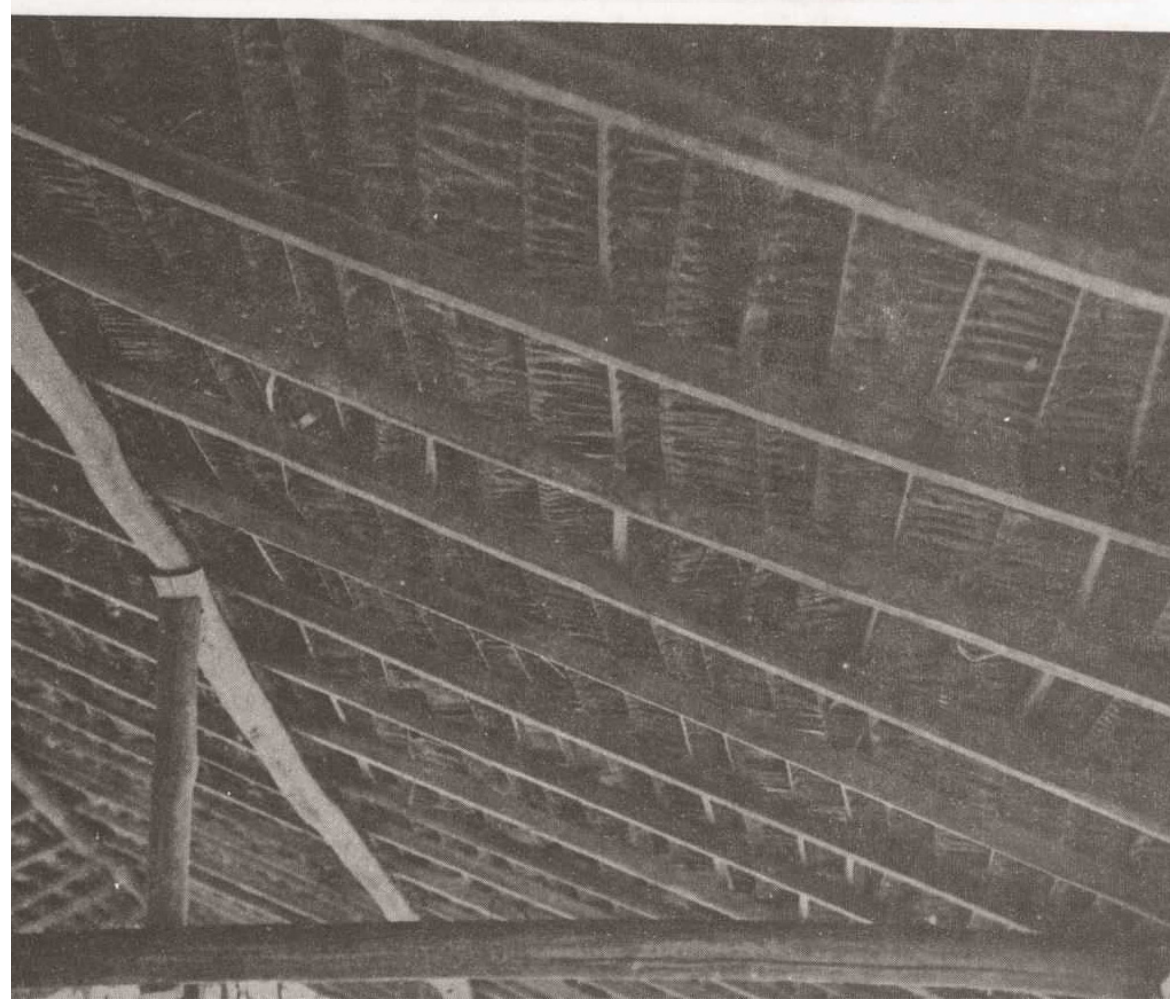

Figura 07. Matéria sobre a técnica empregada na cobertura dos Acampamentos. Fonte: DHNET, 1995. sado para os encarregados a técnica de produção da cobertura de palha (Figura 07).

O Sr. Ribamar lembrou que o Acampamento Escolar do bairro das Rocas, serviu de modelo para os outros que seguiram o mesmo sistema de implantação dos galpões com as mesmas dimensões, o mesmo sistema construtivo e a mesma organização espacial. Houve pouca variação, em alguns acampamentos havia frontões, também feitos de palha e o ripamento unido por pregos. Outro exemplo de pequena variação no sistema dos Acampamentos foi o caso de Aparecida, onde hoje é o bairro de Mãe Luíza. Ali os galpões ficaram expostos ao forte fluxo de vento que entra no continente pelo Sudeste em Natal e foi então necessário construir vedações com painéis de palha trançada nas laterais dos galpões para proteger as atividades.

O Acampamento das Rocas estava localizado em ambiente geográfico dunar, e por isso a vegetação escassa e ausência de barreiras edificadas ou naturais permitia que os ventos do oceano chegassem aos galpões sem nenhum impedimento. A ausência de fechamentos laterais por sua vez, possibilitava que durante o dia a luz invadisse os ambientes não sendo preciso utilizar iluminação artificial nesse período. Em uma entrevista, publicada no PORTAL FORUMEJA (2010), Moacyr de Góes classifica os Acampamentos Escolares da campanha como uma "escola ecológica", dizendo que "o conjunto arquitetônico do 
acampamento, por exemplo, ele está integrado à paisagem, ele não agride a paisagem".

Germano (2010) por sua vez, enfatiza a importância da técnica empregada na construção dos acampamentos para a preservação de uma cultura local:

Conforme se pode notar, o movimento educacional originado da reivindicação popular, expressada através dos comitês e das convenções, tinha agora a arquitetura dos seus prédios escolares sugerida e erguida a construção por operários e pescadores. E, naturalmente, era uma escola simples, com uma arquitetura que refletia as próprias condições de habitação das populações pobres da cidade. Um tal tipo de edificação não só demandava um baixo consumo de mercadorias; como também significava, sobretudo, uma autêntica obra de cultura popular, usada pelos pescadores das praias nordestinas. (GERMANO, 2010, p. 119).

Segundo Manoel Correa de Andrade (1963, p. 88-9), os coqueirais formavam uma paisagem que se estendia desde Itamaracá e Maranguape, localidades próximas à Recife até localidades distantes "emoldurando o litoral da Paraíba, do Rio Grande do Norte, de Alagoas, de Sergipe e Bahia". Essa faixa limitada ao estreito litoral não concorria com as terras para o cultivo da cana de açúcar e permitia a existência de "uma sociedade pobre, democrática que nenhuma sombra fazia à aristocracia dos canaviais". "Além disso, o coqueiral fornecia, fora o fruto, o tronco e as folhas usadas na confecção das palhoças".
A arquitetura dos Acampamentos Escolares se identifica com a habitação vernacular da população litorânea e é a mesma dos mocambos, a moradia pobre que se instalou principalmente em Recife a partir de final da década de 1930. A documentação desta arquitetura vernacular como parte de um sistema cultural completo da formação social brasileira, foi feita pelo sociólogo pernambucano Gilberto Freyre (1900 - 1987), que estudou e registrou os mocambos nesse período (Sobrados e Mucambos, 1936 e Mucambos do Nordeste, 1937). Segundo Freyre, os mocambos são um tipo de edificação primitiva da região litorânea do Nordeste Brasileiro, que apresenta uma influência dominante da arquitetura tribal africana, inclusive a palavra deriva de $m u+k a m b o$, que em quimbundo (língua falada no noroeste da África) significa esconderijo (FREYRE, 1937, p. 20). Freyre descreve os mocambos como:

[...] O mucambo no Nordeste permanece, na sua simplicidade de casa toda ou quasi toda de palha, de folha, ou de capim-assú, um typo de habitação caracteristicamente primitiva. E por sua simplicidade contrasta fortemente com a casa européa de pedra, tijolo, telha, azulejo, vidro, assoalho. (FREYRE, 193, p. 20).

[...] No mucambo de typo mais primitivo não entra prego, mas o cipó ou a corda vegetal de modo a ser perfeito o seu primitivismo e perfeito o seu ecologismo, dado o emprego de material do lugar ou da região e das condições senão ideaes, boas de aeração e insolação desse typo popular de casa. (FREYRE, 1937, p. 28). 


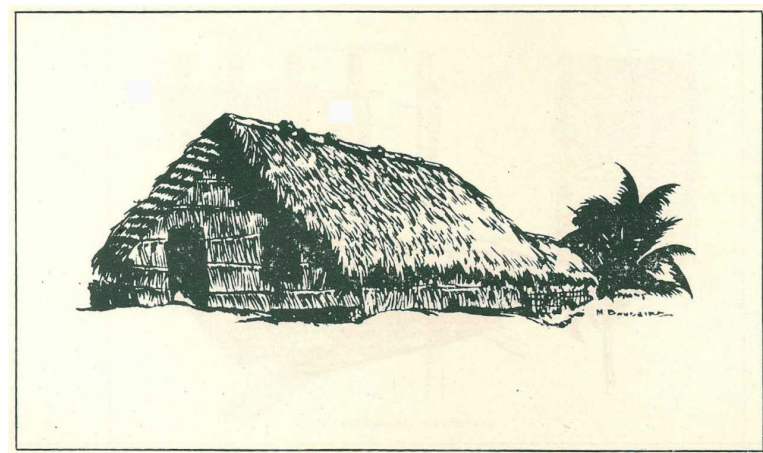

Figura 08. Mocambo de palha de coqueiro. Fonte: FREYRE, 1937

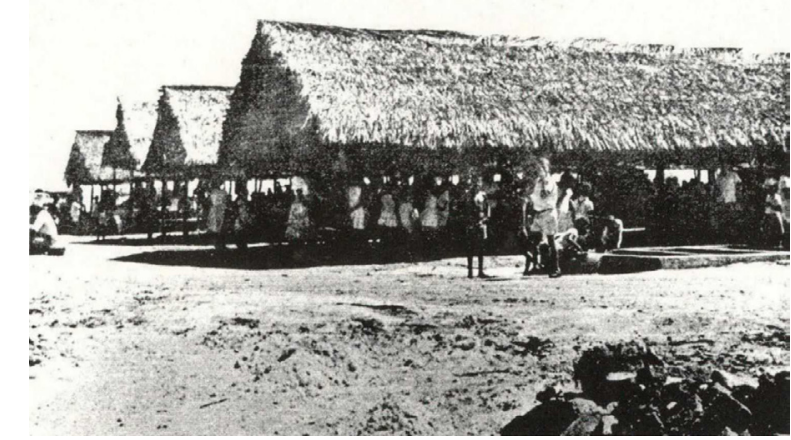

Figura 09. Aspecto de um acampamento escolar, detalhe para a cobertura de palha de coqueiro. Fonte: DHNET, 1995.
A Figura 08, ilustrada por Manoel Bandeira representa os mocambos estudados por Gilberto Freyre, para a primeira revista do SPHAN - Serviço do patrimônio Histórico e Artístico Nacional, em 1937, apresentam características físicas também encontradas nos acampamentos escolares, como é o exemplo das coberturas feitas de paIha, assim como as elevações laterais e fachadas frontais com o mesmo material, também outra similitude está na ambiência geográfica, geralmente dunar.

Segundo Freyre os mocambos atendiam à 'ecologia local' retirando do espaço geográfico o tipo de material para a construção. Assim a variedade era determinada pela diversidade da cultura local e pelas especificidades dos recursos encontrados na região. O professor José Tavares Correia de Lira (1996) explica a leitura ecológica de Gilberto Freyre:

Em Gilberto Freyre, há uma leitura ecológica tradicional, da casa adaptada ao meio geográfico, que se desdobra em características formais e culturais bem específicas: a simplicidade de linhas, a economia de ornamentos, o apoio quase exclusivo sobre a qualidade do material, a honestidade plástica, ligando-se por aí ao fato cultural vernáculo, anônimo e autóctone da produção da casa. (LIRA, 1996, p. 99).

A estética e a técnica empregadas nos acampamentos escolares, assim como a participação popular na construção, apontam para uma relação direta com os mocambos, visto que o modus operandi tem particularidades análogas, característico da região geográfica em que se encontram, o Nordeste do Brasil. É importante apontar que no domínio dessas técnicas construtivas está a relação da cultura popular com a produção do espaço. No caso dos Acampamentos, a população foi agente de uma transformação política que alterou a relação com a sua realidade urbana. Essa foi a situação problema que ligou cultura popular, política de educação e produção do espaço em Natal. A educação na capital do Rio Grande do Norte foi um caminho possível para a ampliação da sociedade democrática urbana no início da década se 1960.

\section{As várias campanhas que complementaram o programa dos Acampamentos Escolares}

A campanha De Pé no Chão não se encontrava isolada como único instrumento que buscava difundir a cultura para a população de Natal, o prefeito Djalma Maranhão trabalhou, também, para que houvesse diversidade de acesso e de formas de expressão cultural na cidade.

Djalma realizou diversos eventos, assim como construiu equipamentos voltados à promoção da cultura popular, dentre os eventos destacam-se as Praças de Cultura.

As Praças de Cultura em Natal eram uma versão adaptada das que ocorriam em Recife. Segundo Góes (2010, p. 92), uma Praça de Cultura em 


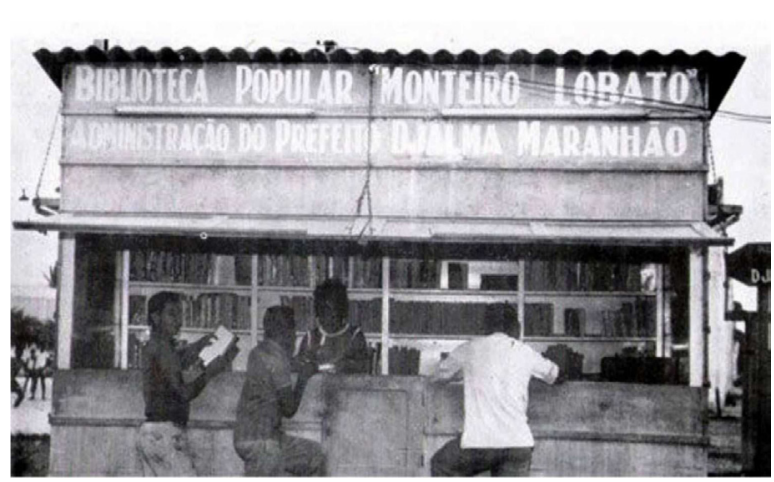

Figura 10. Biblioteca Monteiro Lobato - Bairro das Rocas. D. Nair atrás do balcão. Fonte: DHNET, 1995

4. D. Nair foi bibliotecária e professora durante a campanha De pé no chão. Em sua casa funcionou uma das Escolinhas, antes dos acampamentos escolares surgirem. Relato de $\mathrm{D}$. Nair à autora em agosto de 2017, Natal/RN.

usjt • arq.urb • número 25 | maio - agosto de 2019
Natal "era constituída de parque infantil, quadras de esporte (vôlei, futebol de salão e basquete) e uma biblioteca". Germano entende as Praças de Cultura como um "complexo cultural [...] onde o esporte e a cultura eram desenvolvidos" (GERMANO, 2010, p. 138). A partir da imagem do convite, percebe-se que a Praça de Cultura era também um evento cultural onde eram oferecidas ao público atividades de literatura, música, artes plásticas etc.

Sobre esse aspecto das Praças, Góes revela que:

[...] Aqui há uma verdadeira ocupação de uma das principais praças da cidade, pelo período de uma semana, com a instalação de barracas de madeira para feira de livros, de discos, de artes plásticas (popular e erudita), artesanato; palanques para exibição de autos folclóricos e retretas, audição de coral e jograis; noites de autógrafos dos escritores e homenagens às instituições culturais da cidade. (GÓES, 2010, p. 124).

A política cultural de Djalma Maranhão incluía as bibliotecas, porém apenas dois bairros foram contemplados, Rocas e Quintas. As "bibliotecas" eram postos de empréstimos de livros. Sobre o funcionamento das bibliotecas, D. Nair ${ }^{4}$, que foi professora no Acampamento das Rocas e trabalhou na biblioteca Monteiro Lobato (Figura 10), relatou a autora que: "Quando você precisava de um livro, ia lá e pegava emprestado, devolvia depois de dez dias e se precisasse colocava mais uma data com dez dias". A arquitetura das bibliotecas, a exemplo dos Acampamentos, era rústica, feitas de madeira, como pode ser observado na imagem.

Os livros para as bibliotecas foram arrecadados em uma campanha lançada pela prefeitura. A campanha consistia em um carro de som que pedia à população dos bairros mais ricos, que o livro que estivesse sobrando em casa fosse doado, com isso foram arrecadados os livros para as bibliotecas e para os Acampamentos Escolares. Djalma relatou o sucesso com a adesão popular à campanha:

A comunidade integrava-se, mais uma vez, nas promoções da prefeitura. Velhos, meninos, mulheres, todos queriam doar um livro à Campanha. Havia cenas comoventes de avós que havendo guardado com carinho, livros pertencentes aos seus netos, vinham entregálos para as bibliotecas populares. Crianças arrebatavam livros das bibliotecas de seus pais, destinando-os ao movimento de Pé no Chão, motivados pela legenda "o livro que está sobrando na sua estante, é o livro que está faltando nas mãos do povo". (MARANHÃO, [?], p. 150).

Os livros destinados aos Acampamentos foram postos em caixas de metal, em um total de 100 exemplares em cada caixa. Cada escola recebia uma dessas caixas por um período de um mês, configurando-as como uma espécie de biblioteca rotativa, que permitia que cada acampamento, na prática, tivesse acesso a 900 livros (GÓES, 2010, p. 114). 
Outros programas implantados por Djalma Maranhão além da campanha De pé no chão e das Praças de Cultura foi a campanha De pé no chão também se aprende uma profissão. Nessa campanha eram oferecidos cursos profissionalizantes.

Complementando a Campanha De Pé no Chão Também se Aprende a Ler, surgiu uma outra Campanha: De Pé no Chão Também se Aprende uma Profissão. Destinava-se a dar ao jovem e ao homem alfabetizado, através de Cursos de Aprendizes, os instrumentos profissionais para um Nordeste que vai amanhecendo para a sua industrialização. (MARANHÃO, [?], p. 110).

A campanha De Pé no Chão Também se Aprende uma Profissão iniciou em fevereiro de 1963 com a oferta de oito cursos, em setembro do mesmo ano chegou a oferecer dezessete cursos profissionalizantes e ao final do ano já ofertava trinta cursos distribuídos entre sete Acampamentos Escolares. As modalidades eram: corte e costura, alfaiataria, marcenaria, sapataria, telegrafia, elementos de eletricidade, barbearia, bordado à mão, corte de cabelo feminino, enfermagem de urgência, datilografia, taquigrafia, encadernação artesanato; bordado à mão, bordado à máquina e cerâmica. (MARANHÃO, [?], p. 110).

A última fase da campanha "De Pé no Chão" foi a "Escola Brasileira Construída com Dinheiro Brasileiro" (1963), que ganhou esse nome em contraposição explícita de Djalma Maranhão à atuação da Aliança para o Progresso no governo de Aluízio Alves (GÓES, 2010, p. 99). Djalma recusou-se a receber financiamento dos Estados Unidos, e obteve recursos federais para a construção de escolas em alvenaria, como descrito por Góes: "Sem substituir a escola de palha, a Prefeitura colocava, assim, na paisagem da cidade, pequenas salas de aula de alvenaria, partindo de estruturas metálicas pré-fabricadas, adquiridas com os recursos liberados pelo MEC". (GÓES, 2010, p. 98).

\section{Os desdobramentos da campanha (à guisa de conclusão)}

Os Acampamentos Escolares foram criados para suprir a necessidade de expansão da rede escolar e instituir uma poderosa campanha de luta contra o analfabetismo efetuada com o mínimo de recursos disponíveis. Sua arquitetura vernacular simboliza uma política pública gestada de modo participativo enfrentando as condições de pobreza dos bairros periféricos da capital potiguar. A solução construtiva e espacial adotada pertence ao sistema cultural da população que atendeu, aumentando com isso o potencial simbólico e por que não "monumental" do edifício para a população à que se destinou. O Acampamento Escolar do bairro das Rocas em Natal materializa o projeto político gestado no Comitê Nacionalista das Rocas, a saber, a universalização do acesso à educação pública na cidade de Natal em 1961. 
5. Os quantitativos foram retirados do "Quadro-síntese de De Pé no Chão" de GÓES (2010, p. 203)
Segundo Germano (2010, p. 113) a população de Natal no recenseamento de 1960 era de 154.276 habitantes; e Góes (2010, p. 87) revela que o número de analfabetos era de 60.254 , destes 35.810 eram crianças e 24.444 adultos, ou seja, a taxa de analfabetos na capital, no início da década de 1960 , era de quase $40 \%$ da população total.

Ainda de acordo com Góes, A campanha De Pé no Chão, no período de vigência de pouco mais de três anos, de 1961 a 1964, teve a quantidade de alunos aumentada em quase $600 \%$ (seiscentos por cento), número que nos remete a uma verdadeira revolução no acesso à educação. No mês de fevereiro de 1961 contava com quase 3000 (três mil) alunos matriculados (2974 alunos), e em dezembro já se contabilizava 8000 (oito mil) alunos, quase duplicando em 1962 quando havia 15000 (quinze mil) alunos e, no final da campanha em abril de 1964, chegou ao impressionante número de 17000 (dezessete mil) alunos ${ }^{5}$.

Tais números revelam dois fatores que caracterizam o sucesso dessa campanha, o primeiro foi a expansão territorial dos acampamentos pela cidade de Natal. No primeiro ano existiam apenas dois acampamentos e no final da campanha já se somavam nove. Esses acampamentos levaram um programa cultural abrangente para as periferias pobres de Natal contribuindo para a transformação da realidade urbana dessas localidades. $\mathrm{O}$ segundo foi a atitude da população em busca da educação, havia de fato uma demanda crescente que aliada à vontade transformadora de gestores comprometidos materializou a oferta de uma educação democrática alternativa em grande número de vagas na cidade de Natal contribuindo efetivamente para a diminuição do analfabetismo e para a inclusão das camadas pobres no processo político. O crime de Djalma Maranhão não se completou e mesmo massivamente alfabetizados a população carente de Natal assim como todos os brasileiros foram alienados dos seus direitos democráticos constitucionais pelo golpe empresarial-militar de 1964.

\section{Referências}

I Encontro de Alfabetização e Cultura Popular, 1963. NATAL - SECRETARIA DE EDUCAÇÃO, CULTURA E SAÚDE DE NATAL. Cultura popular e pé no chão. Natal: Disponível em <http://www. dhnet.org.br/educar/penochao/relatorio_1963_ campanha_pe_no_chao.pdf $>$. Acesso em 04 abr. 2017.

ANDRADE, Manuel Correa de. A terra e o homem no nordeste. São Paulo: Brasiliense, 1963.

D’ARAÚJO, Maria Celina Soares. A volta de Vargas ao poder e a polarização das forças políticas e sociais. In Szmrecsányi, Tamás and Granziera, Rui G. Getúlio Vargas e a economia contemporânea. Campinas: Editora da Unicamp, 1986. 
DHNET. Imagens. Natal: DHNET, 1995. <www. dhnet.org.br/educar/penochao/>. Acesso em: 14 dez. 2017.

FREYRE, Gilberto. Mucambos do Nordeste: algumas notas sobre o typo de casa popular mais primitivo do Nordeste do Brasil. Rio de Janeiro: Ministério da Educação e Saúde, 1937.

GERMANO, José Willington. Lendo e aprendendo: a campanha de Pé no Chão. 3 ed. Natal: Palumbo, 2010.

GÓES, Moacir. De pé no chão também se aprende a ler. Apresentação, 1997. Disponível em <http://www.dhnet.org.br/educar/penochao/ apresentacao.htm acesso em 01/05/2019>.

GÓES, Moacyr de. De pé no chão também se aprende a ler: (1960 - 1964) Uma escola democrática. 3 ed. Natal: Palumbo, 2010.

LIRA, José Tavares Correia de. Mocambo e cidade: regionalismo na arquitetura e ordenação do espaço habitado.1996. Memorial de Qualificação da Tese (Doutorado em Arquitetura). Faculdade de Arquitetura e Urbanismo, Universidade de São Paulo. São Paulo.

MARANHÃO, Djalma. De Pé no Chão Também se Aprende a Ler: a escola brasileira com dinheiro brasileiro, uma experiência válida para o mundo subdesenvolvido. Estudo realizado no exílio no Uruguai. Natal: DHNET, [?]. Disponível em: <http://www.dhnet.org.br/dados/livros/potiguariana/djalma_dois_livros_exilio/05_a_campanha_ de_pe_no_chao.pdf $>$. Acesso em: 05 mar. 2019.

\section{PORTAL FORUMEJA. De Pé no Chão Também}

se Aprende a Ler. Entrevista com o educador Moacyr de Góes. [?], 2010. Disponível em: <http://forumeja.org.br/book/export/html/1422>. Acesso em: 03 abr. 2019.

\section{Acervos pesquisados}

Acervo audiovisual da central de documentação do site <dhnet.org.br>. Bairro Tirol, Natal/ RN.

Arquivo Público Estadual. Bairro do Alecrim, Natal/ RN.

\section{Entrevistas}

MONTE, Gabriel. Conversa informal. Arquivo de áudio (1h28min57s), no formato .mp4, autorizada pelo entrevistado. Acervo próprio. Natal: RN, 2017. Concedida em 11 ago. 2017.

OLIVEIRA, José Ribamar de. Entrevista. Arquivo de áudio (46min17s), no formato .mp4, autorizada pelo entrevistado. Acervo próprio. Natal: RN, 2017. Concedida em 12 set. 2017.

OLIVEIRA, Nair Almeida de. Entrevista. Arquivo de áudio (36min24s), no formato .mp4, autorizada pela entrevistada. Acervo próprio. Natal: RN, 2017. Concedida em 10 ago. 2017. 